\title{
How to understand, evaluate and influence efficient progress in South Africa's land reform process: A typology from historical lessons from selected sub-Saharan African countries
}

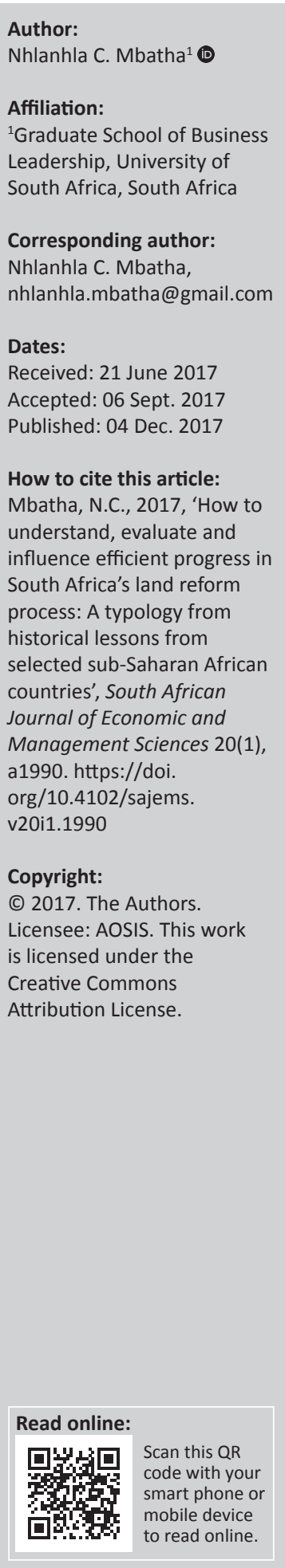

Background: With reports of widespread failures in South Africa's land reform programmes, the levels of policy uncertainty in the political rhetoric that influences land reform have been increasing. Since 1994 policy targets to transfer land to black farmers have not been met. Of the 2005 target to transfer about 25 million ha of commercial farmland to black farmers by 2014, less than 5 million ha. have been transferred for commercial use. Some studies report failure rates in resettlement projects of up to $90 \%$. To account for the failures, revisions of policies and amendments to legislations have been proposed within a political environment that is becoming increasingly intolerant to slow progress in land transfers and to resettlement failures.

Aim: Against this environment, this paper presents a typology for understanding and evaluating important elements of the land reform project in order to influence progress in the process.

Setting: The study adopts a historical review of land reform processes in post-colonial Kenya and Zimbabwe in order to identify potential challenges and key lessons for South Africa.

Methods: Hence, using institutional and historical analytical lenses in exploring different narratives, the paper reviews reported failures and successes in land reform policy cases from the selected countries. From an institutional framework, prevalent social institutions and key lessons from Kenya, Zimbabwe and South Africa, a typology for evaluating important elements of the land reform process in South Africa is developed and discussed. Additionally, a review of global data collected on average sizes of farms in different regions of the world is provided as evidence to support propositions of what would constitute efficient farmland size ranges for small to medium commercial farms in South Africa.

Results and conclusion: A proposition is made on how to use the typology to guide policy and research interventions to reduce failures and promote successful cases in different areas of the land reform process in South Africa, and possibly other similar contexts.

\section{Introduction}

Land reform programmes in post-colonial Africa continue to be challenging as currently illustrated by South Africa's experiences. More failures than successes in reform projects have been reported since 1994. The process to transfer land to beneficiaries in the redistribution programme has remained slow. The plan to create many small family farms is also progressing slowly. In 2005 the revised land reform target was to transfer 30\% of land (about 25 million hectares) to almost 800000 new black farmers. Lyne (2014) estimated that by 2014 a total of only 9 million hectares had been transferred since 1994, in both the restitution and redistribution programmes. This means the redistribution programme achieved only less than $20 \%$ of its revised 2005 target. Fewer than expected claims had been lodged within the restitution programme by 2014. Many of those lodged before 2014 remain unsettled. The Restitution of Land Rights Bill Amendment No. 15 (2014) was enacted to reopen a window for strategic claims to be lodged until 2019. The LRC (2017) reports that of the claims before 2014 about 11000 remain unresolved. After the 2014 Bill, the Land Commission has already received 12464 new claims for processing. These trends highlight the challenges faced with respect to land transfers in the land reform project as a whole. Moreover, in projects where black farmers have been resettled, there is high number of failures in terms of dropping productivity levels. Mbatha and Antrobus (2012) reported that more than $50 \%$ of such projects had failed. Some studies have put the figure at around 90\% (CDE 2008; The Conversation 2016). 
It is clear that the land reform project requires a more logical and easily understood framework to achieve better results. The aim of this paper is to propose a useful framework for the programme, which is also aligned with the aspirations of the country's National Development Plan (2011). Based on reviews of land reform experiences in selected countries in sub-Saharan Africa, of global data on efficient average farm sizes, and of local experiences, a typology to understand different aspects of the land reform project is presented. The typology also provides guidelines for research and policy on areas including progress evaluation of resettlement cases. For instance, the typology illustrates why progress should be evaluated differently in restitution versus redistribution cases.

This study is presented as follows: the 'Methodology' section outlines the methodology adopted for the discussion and a summary of methods used in selected literatures. The 'Literature Review' section reviews historical cases from selected African countries and highlights lessons for South Africa. The 'Discussion and Proposed Typology' section uses key elements from the reviews and data trends to develop a typology for how research and policy should understand, evaluate and influence different aspects of the land reform programme in South Africa. Finally, the 'Summary and Concluding Remarks' section presents a concluding summary of the study.

\section{Methodology}

The primary method used was a review of historical literature on land reform projects in three purposefully selected countries in sub-Saharan Africa. The land reform histories selected for comparative analyses were from Kenya, Zimbabwe and South Africa. Relevant data for validation came from additional African cases, including Ethiopia and Tanzania. The primary cases of Kenya and Zimbabwe were selected because:

- These countries' land reform projects were characterised by a high degree of similar political upheaval (e.g. mass revolts) in the 1950/1960s and the 1990s, respectively. The lessons were relevant for South Africa, whose land crisis is simmering currently.

- The three countries' histories are similar in terms of their colonial British rule, with similar laws and policy thinking that shaped both their colonial and post-colonial trajectories.

- Kenya's transition to a post-colonial state took place two decades before that of Zimbabwe; hence, its review formed the basis upon which a historical comparison could be made between the two countries.

- A sequential list of events from Kenya and then Zimbabwe was synthesised to establish a lens through which the South African case can be analysed.

Therefore, this discussion is a comparative analysis of similar land reform projects in selected parts of sub-Saharan Africa that were British colonies. In South Africa, the review had two approaches. A historical presentation of an evolving land reform policy landscape is presented alongside a review of ethnographic cases in two regions (Limpopo and KwaZuluNatal). The local resettlement data come from cases of sugarcane farmlands of KwaZulu-Natal (Mbatha \& Antrobus 2012; Mbatha et al. 2010), as well as community settlement cases presented by Terblanche, Stevens and Sekgota (2014). Throughout the discussion, a reflection on what threads run across the international and local cases is compared for general and specific themes. Moreover, quantitative data on global average farm sizes were reviewed from secondary sources containing data from different regions. These data on average farm sizes were collated by Lowder, Skoet and Raney (2016:16-29) from representative agricultural censuses of all farms globally. These include survey data from the Programme for the World Census of Agriculture (WCA) collected since 1950 on about 160 countries. For these surveys Food and Agriculture Organization (FAO) provides governments with a methodology to be followed. Lowder et al. (2016) reported that from 1930 to 1980 the data were collected twice a year, but from 1990, with improved standardisation, it was collected only once annually. For this discussion, historical data that were grouped by geographical region and incomes were used to identify trends by the same variables (region and income) to argue for what would make for efficient average farm sizes in the context of developing countries. Other historical reviews of average farm size data in Asia from Ahmad and Quresh (1999) are presented to support selected parts of the discussion. In summary, the paper presents and analyses, for common trends and themes, mostly historical and qualitative data from purposefully selected countries. The paper also presents quantitative data from studies that analyse global data on average farm sizes to propose a range of what would constitute small but efficient farms locally. Ultimately the data are used to develop a typology for understanding different historical elements of land reform projects in selected African countries and how those elements would need to be approached to avoid similar challenges from recurring in South Africa. The typology is also useful for identifying policy areas that may be replicated for their successes.

\section{Literature review}

The review starts off with a presentation of the land reform process in South Africa. This is followed by a historical review of Kenya's land reform and lastly a review Zimbabwe's land reform history. Key issues are summarised from the Kenyan and Zimbabwean experiences for lessons for South Africa's land reform project.

\section{An overview of challenges in South Africa's land reform process}

Lyne and Darroch (2003), Centre for Development and Enterprise (CDE 2008), Lyne (2014) and Mbatha and Muchara (2015) provide some of the important economic accounts and analyses of the land reform programmes in South Africa since 1994. More sociological accounts and analyses are discussed by Neves (2006) and Hall (2009). They all present cases of negative effects of racial segregation achieved by the state through Apartheid policies founded on the Natives Land 
Act of 1913. They show that segregation policies ensured that $87 \%$ of land was owned by white people with the only $13 \%$ in the hands of black people, in what were 'homeland reserves' before 1994. Logically the effects of unequal racial ownership of resources would cement other inequalities along racial lines. In attempts to redress the effects the democratic government, post-1994, would use three approaches in the land reform project, namely, land restitution, land redistribution and land tenure upgrade.

- The aim of the Land Restitution Programme (Restitution of Land Rights Act (22) 1994) was to return land to communities that were moved forcibly through the Land Act (1913). After 1994 communities were allowed to lodge land claims until 1998 (Neves 2006:200). In 2014 elements of the land restitution process were extended for 5 years to allow for the return of land earmarked for strategic areas including heritage sites and historic landmarks. From this process more than 12000 thousand claims have been received by the land commission (Legal Resources Centre (LRC) 2017).

- The aim of the Land Redistribution Programme was commercial in nature and was to facilitate the transfer of land to black farmers for business use through the government grants. This process has also faced challenges in terms of the rates of land transfers as well as poor or failed commercial uses after transfers (see Mbatha et al. 2010).

- The aim of the Land Tenure Reform was to extend security of tenure in former homelands as well as to extend tenure to farm workers and tenants on commercial farms. The approach has also met challenges given conflicting interests of stakeholders. Conradie (2007) reported cases where the process to extend tenure to black workers led to them losing jobs.

Low transfer rates of land, partly blamed on unresolved claims and disputes on land prices for land acquisition in the restitution and redistribution programmes, as well as low productivity rates in land earmarked for commercial uses have characterised South Africa's land reform processes. With respect to land prices, the market systems (Willing Seller) used to acquire land by government in both programmes have also been challenged. The constitutional principle of compensating land owners at market related prices for land identified for the restitution or redistribution (Department of Land Affairs (DLA) 1997; Mbatha et al. 2010) has been identified by some as one of the factors contributing towards low transfer rates. This was clear at South Africa's Land Summit in 2005 where the Willing Seller framework was under discussion for possible review (Mbatha et al. 2010). Post 2005, questions on the appropriateness of the framework have remained (if not intensified) in political debates. In the 2013 national address, the South African president stated that 'we must shorten the time it takes to finalise a claim. In this regard, government will now pursue the just and equitable principle for compensation, as set out in the Constitution' (State President 2013). To eliminate some of these challenges, a number of amendments to legislation have been passed by parliament including the Restitution of Land Rights Amendment Bill Act No. 15 (2014) to accommodate strategic land claims, and the Property Valuation Act No. 17 (2014)to establish just and fair prices through the Office of the Valuer-General. The developments indicate the complexity of concerns in land reform processes whose details are presented below.

By the end of 1998, only 68000 claims had been lodged with the Land Claims court. From those claims only 12623 households had benefitted from about 268306 hectares in 2000 . This was only $1 \%$ of total land available for redistribution. The process got some momentum when then State President instructed officials to finalise all pending claims by 2005 (Lyne \& Dorroch 2003). Nevertheless many claims still remain unresolved in 2017, especially with the Restitution of Land Rights Bill Amendment No. 15 (2014) having reopened a window for claims to be lodged until 2019. From the process prior to 2014 about 11000 claims had not been resolved. After 2014 the Land Commission received an additional 12464 claims for processing (LRC 2017). This means that challenges with respect to land transfer rates will remain for some time. Of land that has already been transferred many farms are reported to be lying idle. Different studies have reported between $50 \%$ and $90 \%$ of resettlement projects that have failed (CDE 2008; Mbatha \& Antrobus 2012; The Conversation 2016). These cases are what Tuner and Ibsen (2000 in Lyne \& Darroch 2003:3) labelled as the 'new rural "dumping grounds" that were...linked to (no) development process that (offered) livelihoods to beneficiaries'. Based on these reports, the primary purpose of this discussion is to propose a typology for intervention to promote success cases in the whole process.

\section{Lessons from a review of selected farmer cases}

In a review of South African experiences in establishing emerging farmers the FAO(FAO2009) found that implementing and overseeing agencies themselves lacked the required capacity to execute their work. For the redistribution programme, the review proposed that a more rigorous selection was required to identify beneficiaries. Incentives to promote performance have to be designed; there has to be better coordination and cohesion among service providers in the land reform process. Improved skills on use of technology, finance and farm management and market information are some of the basics required for the productive use of farmlands. Successful cases, on the other hand, were characterised by:

- sound business plans that were developed and owned internally

- farmers who possessed most of the required skills to execute their own plans

- an alignment between the plans and physical as well as natural resources available to farmers

- an access to inputs and output markets

- farmers who had a voice to shape policy.

Terblanche et al. (2014) reviewed performances of two restitution cases in Mashishimale (Limpopo province) and Nkumbuleni (KwaZulu-Natal province). Both cases had 
hundreds of households forming part of each community. In the first case a Community Property Association $\left(\mathrm{CPA}^{1}\right)$ was established to act on behalf of the community's interests, while a Community Trust (CT) was established in the second case. The CPA's responsibilities were clearly defined with a strong business plan and it appointed skilled managers to run different businesses on the farm. The CT's responsibilities and functions, in the second case, were not as detailed. The CT appointed a strategic partner to manage business processes on its farms. In the end more successes than challenges were reported for the CPA compared to the CT case. In addition Mbatha and Antrobus (2012) reported on more than 30 transaction cases under the land redistribution programme in KwaZulu-Natal's two district municipalities of iLembe and uThungulu. They found that cooperative partnerships between outgoing and incoming farmers maintained or improved production levels on farmlands in post transfer periods. The partnerships ensured that critical skills and market networks were available to incoming farmers. These cases emphasise the importance of clear plans, boundaries, skills, networks and markets - noted in FAO (2009) as attributes for success cases.

\section{A review of selected countries in sub-Saharan Africa}

The aim of this subsection is to highlight key issues from the Kenyan and Zimbabwean land reform experiences. Lessons from these issues are then used to develop a typology to guide the land reform process in South Africa.

\section{An overview of the reform process in Kenya}

There are parallels in some colonial events and political trends between Kenya and South Africa. Harbeson (1971) presents a political discussion of specific key events of the period before and after independence in 1963 from the 1950s to the 1970s to propose that the land process was used more to manipulate African politics in the country as opposed to promoting economic development. Kanyinga (1996) presents an overview of different policies and their impacts over time, and Rutten (1997) highlights some lessons for South Africa from the Kenya experience, especially on the usefulness of group versus individual tenure. In Kenya, like in South Africa, there was deliberate alienation of Africans for the acquisition of land as preludes to the establishment of a colonial state. 'Through force, the colonial state subdued different communities opposed to land expropriation' (Kanyinga 2016). This resulted in a situation where 'Africans worked on European farms they were not permitted to buy, and Europeans and Asians operated businesses even if they did not own land in African areas' (Harbeson 1971:231). Mamdani (1996) describes how the state's legislation created reserves for 'natives' away from areas demarcated for white European settlers. In South Africa, there was a creation of homelands, which acted as reserves for black labour surplus for the white economy on white farmlands and mines (Mbatha et al. 2010).

1.The CPA is a legal body though which members of disadvantaged communities may collectively acquire, hold and manage property in terms of a written constitution (DLA 1997:51).
These events led to population congestions and land erosion in black reserves, leading to political revolts against the state in both countries. The historical differences in these events are also pronounced. For example, while in Kenya there was an active effort by the colonial state to promote private property rights over 'diffuse collective rights' including in the reserves, in South Africa land rights and control remained mainly under tribal authorities in homelands. This is an important difference to note for this discussion as we explore further points for comparison in selected country cases previously under the British colonial rule in Africa. Kanyinga (2016:3) and Harbeson (1971) argue that the promotion of private property rights to land in Kenya's native reserves was to keep them preoccupied in their holdings while preventing them from participating in revolts against the state. Harbeson (1971) further states that the land reform was deliberately used as a tool to counteract the development of African politics especially in rural communities. In South Africa the establishment of semiautonomous governments in homelands as custodians of local tribal authorities may have had a similar effect of keeping black people preoccupied with their internal tribal politics. Ultimately, the resulting racial inequalities in terms of land ownership and access between white people and black people in both countries are comparable. In Kenya's 365000 sq. km, only about 32\% (113 $920 \mathrm{sq} . \mathrm{km}$ ) is arable. Of this arable land (113 920 sq. km), about 21360 sq. km (18.25\%) was owned and controlled by only 3600 white families, while 6 million black people occupied the remaining 84000 sq. km (74\%) (Kanyinga 2016). Rutten's (1997:73) Gini-coefficient on unequal distribution of land holdings was 0.77 in 1980. At this time, 'almost $32 \%$ of all rural households (were) estimated as having holdings of less than 1.0 ha of land'. These are huge ownership inequalities but still better than those reported for South Africa in 1994, where white people owned $87 \%$ of land resources, with only $13 \%$ owned by black people (Mbatha et al. 2010).

Harbeson (1971) argues that the land reform processes to reverse the ownership disparities in transition from colonial to post-colonial Kenya were political and strategic in nature, crafted to work against the development of African politics. They were also marked by policy trial and errors. To a degree this seems to be the case in South Africa too, where 'the land question' remains highly political. However in South Africa there is yet to emerge a cohesive strategy to deal with the politics of land (Lyne 2014). While some policy reforms in Kenya worked effectively to reduce political instability, which was a key objective, they did not achieve economywide goals of increasing land use for both subsistence and commercial production. Some key lessons from Kenya are summarised alongside those of Zimbabwe after the following subsection.

\section{An overview of the land reform process in Zimbabwe}

The reviewed land reform case for Zimbabwe is divided into two phases. The first phase was after independence from 1980 to 1990 and the second phase was after the elapse of the Lancaster agreement in 1990. Overall, political factors, as opposed to economic challenges at farm management level, 
have had a greater determination on the direction to which the land reform process has gone after 1990. The first period of the reform before 1990 was characterised by a design and implementation of technical policies, with some success stories recorded. The period after 1990 was on the other hand characterised by a politicisation of the land reform process with dire outcomes recorded for the reform process and for the whole economy. ${ }^{2}$ This appears similar to what Harbeson (1971) reported for Kenya between 1950s and 1970s. At a political level and under 'power-sharing' arrangements, Cliffe (2011) presents a sophisticated comparative study of Zimbabwe and Kenya's land reform projects. The study illustrates that like in Kenya as well as in South Africa, the land reform process in Zimbabwe had a number of phases with different approaches and objectives stemming from slow progress made and political factors as described by Moyo (1986); Kinsey (1999); Thomas (2010) and others. At independence Zimbabwe, like Kenya and South Africa, inherited high inequalities with respect to land redistribution along racial lines. Almost $70 \%$ of farmland was occupied by white people and only $23.5 \%$ by black people, who formed the majority of the population. White commercial farmers occupied 15.5 of 33.2 million hectares of land while black smallholders occupied only 1.6 million hectares, and the rest was occupied by 750000 subsistence households. Thomas (2010) reports that the average farm sizes of commercial black farmers were a maximum of 20 hectares while those of white farms were as large as 3000 hectares. These are the extents of land inequalities that most African governments have had to contend with after independence. While it is clear that Zimbabwe and Kenya were characterised by a greater hunger for land by their masses, ${ }^{3}$ in South Africa this attribute has not been dominant so far. The hunger for land led to mass invasions of farms in both Kenya and Zimbabwe. This has not yet been the case in South Africa.

The Land Reform and Resettlement Programme (LRRP) in Zimbabwe began with what seemed like reasonable frameworks and objectives for the 10-year Lancaster agreement between the UK and the Zimbabwean government. There were clear guidelines on how land would be acquired and used for resettlements as well as objectives for transfer targets. For example, 8.3 million hectares of land was targeted for redistribution to about 162000 households. For 10 years the land rights of white farmers would be protected with funds set aside for compensations if such rights were abused. The British Aid would fund land purchases from Willing Sellers at market prices. The UK would fund $50 \%$ of black farmer settlement costs. Compulsory purchases would only be affected where land was underutilised by current owners (Thomas 2010).

At farm management level, like in Kenya, individual rights and smaller holdings for new black farmers were preferred. Ninety per cent of schemes had farm sizes of around 6-7 hectares leased to individual farmers, and only $10 \%$ were

2.While all Zimbabwean experiences (positive and negative) are useful for South Africa to learn from, it also appears that most of the positive experiences for Africa to learn from, it also appears that most of the positive experiences

3.Especially in East African countries, such as Ethiopia, growing populations and high demand for land have contributed to allocations of smaller and unsustainable farms (FAO 2015) under the collective management of cooperatives. The resettlement programme also dictated what and how much was produced to ensure that high levels of productivity continued in post transfer periods. Underutilisation of land would lead to revoking of leases from new farmers. Although very few farms were transferred between 1980 and 1989 (i.e. 2.1 of 8.3 million hectares) there were reported cases of success in the programme. To a degree, the lessons of success in Zimbabwe before 1990 mirrored those reported for Kenya.

Moyo (1986, 2000) and Thomas (2010) reported on some of the internal political factors that led to failures in the resettlement programmes after 1990. The factors included a lack of willingness to sell by white farmers stemming from burgeoning land prices as well as measures to contain an increasing budget deficit by fiscal policy. Externally, the effects of trade liberalisation on agricultural output which formed part of Structural Adjustment Reforms promoted by institutions including the IMF appear to have had the most negative impact on Zimbabwe's land reform project. Under trade liberalisation programmes, the removal of import trade barriers meant an increase in relative local farming costs especially for small black farmers who were forced to shut down. IMF's insistence on cutting government spending also had an effect on the level of support given to emerging farmers. After 1990, with low land transfer rates, the government changed its approach to the reform process to ensure that land acquisition targets were met through the Land Acquisition Act. In this second phase, compulsory acquisitions with little compensation were instituted. In the LRRP, farms from absent land lords, underutilised farms and those owned by farmers with more than one property were identified for redistribution at low compensation. The international donor community and the UK government did not support the new approach and without external support for internal spending the Zimbabwean economy collapsed (Thomas 2010). While a number of factors outlined in the lead up to the macro-economic collapse after 1990 seem technical in nature, they cannot be separated from the country's politics, as was the case in Kenya (Harbeson 1971). It must be noted that while there have been great losses reported for Zimbabwe's economy, there have also been emerging reports of social gains, especially around improved land access and social justice for a large section of the population (e.g. Scoones et al. 2010). To evaluate the net effects of the country's key reforms, future studies would have to estimate and weigh overall reported costs against benefits. This discussion is deliberate (with limitations) in focusing mostly on technical factors and their impacts at macro-economic and farm management levels. Such factors, without telling a complete story, are singled out purposefully to draw out useful historical lessons for comparative analyses across the three countries. Below a synthesis of key lessons from Kenya and Zimbabwe is presented for possible lessons for South Africa.

\section{Key lessons from Kenya and Zimbabwe}

The Kenyan and Zimbabwean land reform projects provide general and specific lessons which are useful for noting in South Africa: 
- In Kenya it was shown that acquiring huge loans, from institutions like the World Bank to purchase farms for the land reform project may not be a sound option without effective plans on how new farmers would contribute to the government's servicing of such loans (Harbeson 1971; Kanyinga 2016; Rutten 1997). In Zimbabwe, the overreliance on international donors for the land project and the general public funds within the Structural Reform programmes proved catastrophic for the economy in the end.

- An appropriate mixture of individual or group ownership rights in Kenya could be used where there were clearly defined desired effects and objectives for each choice (Rutten 1997:71). In Zimbabwe more emphasis was put on individual management and ownership of land (i.e. $90 \%$ ) versus $10 \%$ of cooperative ownership. Nevertheless both models could work with clear definitions and guidelines.

- Linked to the previous point, land reform schemes should not cater only for economic activities but should satisfy other needs, such as social justice, around land ownership by the majority of the population. It is true that livelihood activities do not and should not only relate to agricultural production, but other economic activities that would improve social welfare. ${ }^{4}$ A similar point to this one is highlighted in Section four for South Africa in discussions of other possible sociological uses of land that should also be permissible, especially in the restitution programme.

- The demand and ownership of land by as many people as possible in Kenya, over and above efficiency considerations, also contributed to smaller farms being owned by individuals -not in excess of what is globally considered big farms (i.e. 20 hectares) (Lowder et al. 2016). The Zimbabwean case supported a similar conclusion indicating that smaller farms (about 6 to 7 hectares) especially in the 1980s were more efficient in terms of utilising available land resources. It is also noted that while farms tend to be smaller in East Africa where there is more demand for land by the population, in Southern Africa farms owned by black people are slightly bigger. Nevertheless the average size range for efficient land use seems to be between 2 to 5 hectares, depending on factors including actual demand for land, climate, the type of production, technology (as we see later for Asian cases), etc. In both Kenya and Zimbabwe evidence shows that big farms tended to be underutilised.

- The Kenyan story shows that there has to be incentives for resettled farmers to keep their units productive, for example, through requirements to share settlement costs with government. In Zimbabwe the threat to evict nonperforming farmers was used to ensure continued productions in the 1980s.

- In Kenya, collective owners could hire farm managers to supervise production with owners sharing profits. This seems to have also been successful in selected South African cases.

4.This is an important point to stress that even though the focus of the present discussion is limited mostly to land reform objectives aimed at improving agricultura productivity, additional opportunities exist outside the agricultural sector, for productivity, additional opportunities exist outside the agricultural sector, for
example, in mining. Those need to be explored in a similar and systematic fashion as done in the current discussion.
- In both Kenya and Zimbabwe where politicians, government officials or the elite acquired farmlands, the land was often underutilised and this is a lesson to be avoided in South Africa.

- In Kenya and in South Africa, it is shown that legally defined rights to own land (as a group or individuals) lead to better economic land usage than diffuse ownership rights.

- Collective farms are best suited for meeting subsistence farming and the general population hunger for land access. In South Africa subsistence farming seems more applicable to restitution than redistribution cases.

- In Kenya, smallholders would often need off-farm incomes to support their farming businesses. This should be recognised and planned for in South Africa especially where land is used mostly for subsistence farming and other sociological reasons.

- The challenges presented by the Willing Seller framework in Zimbabwe have already been identified as contributing towards slow land transfer rates in South Africa. A distinction between the Willing Seller framework and compensation at market prices still needs to be made. The two concepts present separate challenges and they should not implicate each other. In Zimbabwe failing to pay market related compensation presented additional political challenges to land reform projects.

- Finally, the Zimbabwean case, especially, showed that the success or failure of land reform programmes also depends on external economy-wide factors as well as international variables. Hence the management of the economy as affected by international factors will also have a bearing on how the land reform process unfolds in South Africa. Growing levels of joblessness and decreasing economic opportunities in secondary and tertiary sectors could increase demand for farms. This will put further strain on land reform projects which are already struggling to succeed.

\section{Discussion and proposed typology}

The issues identified in the preceding reviews inform the discussion aimed at developing a typology to understand holistically the land reform process in South Africa. The typology is also useful for identifying areas for policy intervention to achieve better results at improving land transfer rates and agricultural productivity. As indicated already, the main challenges in South Africa's land reform project have two tiers: (1) the low transfer rates for both restitution and redistribution programmes, and (2) the underutilisation of land in post transfer periods. Issues around the subdivision of farmlands, subsistence and commercial uses of land cut across the two tiers of challenges. A comment was made by Lyne (2014) and in the Mail and Guardian (2015) that the Land and Agrarian Reform Project (LARP) now:

proposes that government would $\ldots$ be responsible for purchasing and sub-dividing the land into smaller plots, ${ }^{5}$ selecting the right tenants with demonstrable skills to farm

5.It must be noted that the Subdivision of Agricultural Land Act (1970) founded on the id that smalion agriculturalland in of Agricultural Land Act Repeal (Act 64 of 1998) it remains effective until the legislature 'chooses definitive course of action', - instruction from the Constitutional Court in 2008 (Frantz 2010). 
productively, leasing the land to selected communities or individuals, monitoring their performances, evicting nonperformers...Those who succeed commercially would be given an opportunity to purchase the land at market value. (p. 12)

This is a positive development in policy thinking and seems responsive to many research questions raised over the years. Although challenges still remain with respect to the specifics, for example, around the lack of coordination in implementing such objectives, the lack of tradableownership rights after subdivisions and allocations have occurred and the lack of models on business management under collective versus individual access or ownership. To these, Lyne (2014:4) reported that about:

twenty hectares of land, on average, were allocated to a household during the (LARP) process. That land did not translate into family-owned farms or businesses; the majority translated into community trust owned or operated farms with obscurely defined property rights. Those rights have been in the form of voting and benefit rights in such trusts or community property institutions. And therefore incentives for doing business through investing time, money and effort in farming under such institutional arrangements have been compromised. (p. 4)

These mean that challenges would persist in preventing successful land transfers and productive land uses, especially in redistribution cases. Given the status quo this section presents a typology that brings a higher level of clarity and cohesion in the process of acquiring and allocating land appropriately to different types of land reform beneficiaries in restitution and redistribution programmes. The framework is also useful for evaluating and analysing progress for the effective use of appropriate incentives. It also provides guidance on how land would be subdivided, owned, managed and used by groups or individuals for subsistence, commercial farming and other sociological uses.

\section{A typology for managing the land reform project for economic benefits in South Africa}

Although points are made about other possible sociological uses of acquired land by communities and individuals in post transfer periods, specific attention is given to the second tier of challenges that have been outlined in preceding sections. Those relate to reported underutilisation of agricultural land in resettlement cases. The limitation of the typology presented is that it does not give guidance on how land can be used for other sociological or economic purposes outside agricultureand specifically crop cultivation. Nevertheless, from policy making at a national level to productive activities on land, the motivations are made in the typology for inclusion of logical thinking to promote effective:

- land ownership and management in terms of appropriate property rights

- subdivisions of land for a variety of land uses

- dis/incentives to promote desired and stated objectives on land use

- public policy coordination.

Beyond the land reform process, this framework also informs the character of a 'capable and developmental state' espoused in Chapter 13 of the National Developmental Plan (2011). Among others, such a state should demonstrate:

- institutional competence with low transaction costs; embedded, autonomous and competent bureaucracies, well defined property rights, compatible incentive schemes

- investments in people, skills, technology and innovation.

Building from our earlier research (Mbatha \& Muchara 2015) the current discussion acknowledges the importance of understanding the different types of land uses that may be promoted under different types of ownership rights available to land recipients, and summarised in Table 1.

\section{A continuum of land ownership rights}

It is illustrated that on the one extreme, undefined ownership rights would most likely lead to poor land management in line with the tragedy of the commons thesis (Hardin 1968). Somewhere in the middle, collective or communal rights would support a mixture of subsistence and commercial or competitive use of land.

From the table the promotion of clearly defined rights to own or use land is foundational to successful land protection and thereafter commercial use. This was also observed as a limiting factor in the development of land markets by Lyne (2014) referring to the LARP. This discussion also acknowledges that while most restitution cases have involved community groups and would most likely lend themselves to collective ownership rights, redistribution cases with commercial objectives should lend themselves to individual ownership rights. This however is not a rule cast in stone. There could be individuals laying claims under restitution and vice versa. Nonetheless a policy decision to support and develop clearly defined - even if varied - ownership rights to

TABLE 1: Land rights ownership and use continuum.

\begin{tabular}{|c|c|c|c|}
\hline \multirow[t]{2}{*}{ Type of access or use rights } & \multicolumn{3}{|c|}{ Extent } \\
\hline & Zero rights & $\begin{array}{l}\text { Communal/traditional } \\
\text { rights/insecure tenure }\end{array}$ & Individual and exclusive/tenure \\
\hline Type of governance structure & No governance & Collective governance & Free competitive markets \\
\hline $\begin{array}{l}\text { Technical attributes } \\
\text { (approximate example) }\end{array}$ & Non-visible and non-excludable (solar energy) & $\begin{array}{l}\text { Non-divisible or non-excludable } \\
\text { (lake water) }\end{array}$ & $\begin{array}{l}\text { Divisible and excludable } \\
\text { (e.g. land) }\end{array}$ \\
\hline Socio-political choice & Unlimited access/use to all & Limited access/use to members of group & Individual access/use \\
\hline Social/individual identity & None & Strong group identity & Strong individual identity \\
\hline Type of farmer possible & Ad hoc / subsistent & Subsistent/part small commercial & Subsistent/part small commercial full commercial \\
\hline
\end{tabular}

Source: Mbatha, N.C. \& Muchara, B., 2015, 'Slow progress in South Africa's land reform process: Fear of property rights and free markets?', Journal of Green Economy and Development 1(2), p. 5, viewed 10 April 2017, from https://journalofgreeneconomy.wordpress.com/jged-volume-1-issue-2/ 
groups or individuals is advocated strongly for successful land reform projects. Without clarity of what rights are permissible under traditional systems, collective management systems and individual ownership, many land reform projects cannot be successful.

There are also different types of land ownership associated with different types of rights (Table 1). Without rights to access or use of resources, no group or individual can claim true ownership of resources. At one extreme, in African traditional systems households normally have access rights to land use while the traditional leader is the custodian of the community's ownership rights. The understanding is that chiefs would sanction other legitimate sociological uses on land, for example, including clan gatherings for warship purposes (Neves 2016). In land reform projects traditional leaders should be granted collective ownership title deeds to specified land areas by the state. The leader in consultation with his subjects would then make long term strategic decisions on how land resources are used. The restitution programme especially should be equipped in designing models for how traditional communities would own and use land collectively and fairly (Ostrom 1992). Some ownership models already exist, for example, Community Trusts that own businesses such as mines. The models could be adapted to land reform projects.

Ownership regimes could range from traditional to group (or collective) systems (e.g. Community Trusts) to individual private property rights. While both the restitution and redistribution programmes would deal with any of these types of land ownership regimes (or combinations thereof), it should be anticipated beforehand that traditional and collective ownership systems would mostly arise in restitution cases (e.g. cases in Terblanche et al. 2014).

Individual land ownership rights on the other hand should be anticipated in redistribution cases. In redistribution cases it is up the state to subdivide land for efficient agricultural economic usage. ${ }^{6}$ This should be the case even if it is a traditional community that acquires redistributed land through public funds. As noted by Lyne (2014) the subdivisions in redistribution cases should enable the development of land markets. Such land should always be used commercially irrespective of whether it is owned or leased to a community or an individual. While the land is under lease occupants must be monitored for performance and appropriate incentives should apply them to promote full utilisation of land.

\section{Operational principles for collective bodies}

Where land resources are owned collectively (e.g. CPA), it is important to note Ostrom's $(1990,1992)$ principles in their establishment and operations. This would be done to avoid their misuse and mismanagement. She advocated among

6.In the current discussion economic use is limited mainly to agricultural land use, even though it is acknowledged that economic uses of the land could and should be open to a wide range of other uses for social benefits. Promotions of other efficient economic uses, other than agriculture, would however most probably require different approaches and typologies to be developed. other things that (1) boundaries (physical, legal, etc.) are defined clearly, (2) governance rules match local needs and conditions, (3) those affected by rules should have power to change the rules and these powers should be respected externally, (4) members must have an acceptable system to monitor one another, (5) there should be graduated sanctions for rule violations, (6) resolution of disputes must be easy, cheap and accessible to members, (7) responsibility to govern resources must be nested in the whole system. These principles should apply to production decisions and business management (e.g. profit sharing in collective entities including traditional systems for business sustainability).

\section{Land ownership versus land/business management}

Land can be owned and managed by the same person or group of recipients in both the restitution and redistribution programmes and under collective or individual rights. However, this should not be a rule cast in stone. Ownership of land should not imply farmland management by the same entity. The Kenyan experience presented cases of successful land owners hiring skilled on-farm managers leading to effective productions. South Africa already has cases where groups of land recipients under the restitution programme, represented by CPAs, have hired skilled managers of businesses while the CPA with community members make only long term strategic decisions(e.g. how the land should be used). In those cases the roles of owners are separate from those of managers, given the required set of skills for different business tasks (Terblanche et al. 2014). Different aspects of business management along the supply value chain can also be allocated to different managers based on the best skills available. The long term strategy of the CPAs should then include developing critical business and other required skills among land recipients to insource task performances whenever possible. ${ }^{7}$ The role of extension services is critical in building such skills.

\section{Land uses in restitution versus redistribution cases}

In restitution cases involving communities, the collective would normally make decisions on how they would use their land assets through the CPA. In traditional communities, an appropriate traditional system would apply. At a policy level, information and data on many use options, including commercial business options, should be made available to all recipients for them to make decisions that would improve their welfare. Neves (2006) discusses many other valid land uses which may be noncommercial in nature, including using different portions of land as burial sites, places of warship and community gatherings, nature conservation, etc. These activities should be acknowledged and valued equally to commercial uses (agricultural and others) of land by researchers and policy makers in restitution cases.

7.These proposals are meant to assist current and future cases in the land reform process; however, their practical application should not exclude past cases wherever possible, especially where reforms have been a failure. It would be expected that each one of the past (and failed) cases would have their own dynamics which would or may require different steps and legal considerations to resolve and bring update. or may require different steps and legal considerations to resolve and bring update.
Finding workable and context specific solutions to past cases that went wrong need to be done. 
When communities decide to use their land only sociologically in restitution cases this should not imply case failures. Communities may not necessarily have commercial aspirations for their land resources. This needs acknowledgement by policy, even if such sentiments may not seem aligned with the attributes of a developmental state, ${ }^{8}$ whose main objective could be economic empowerment. Access to land for warship, for example, and social justice are also valid enough motivations for land reform as reported in some Zimbabwean cases. Nevertheless land uses in restitution cases could also be a mixture of sociological and commercial activities. It could also be a mixture of subsistence farming alongside commercial farming. But when public funds are used to acquire land it is the responsibility of a developmental state to dictate how the land is subdivided and used productively to improve socioeconomic welfare. Different types of incentives to promote productive use of land should also be designed when public funds are used in restitution or traditionally owned areas. Other community assets should be identified for surety in cases where public funds are lost because of non-performance in commercial agricultural ventures. The guiding principles should be for public funds not to be invested: (1) without guarantees of performances and (2) without incentives in place to promote performance.

Land uses in redistribution cases should be clearer. The main objective of the programme is to promote commercial use of land. The LARP has put in place a framework to select potential black farmers who are likely to succeed commercially. When farmers are not performing commercially they would be evicted and those who perform would be given a chance to purchase the land at market value. The level of production and commercial success form part of an evaluative framework, irrespective of whether the land is owned by a group or an individual. Ultimately, the production level should be such that farmers are able to meet their monthly contributions in land purchases. A framework should be developed for when it can be accepted that farmers are not performing at the right level or have defaulted. Less stringent conditions may be adopted compared to measures used by commercial banks. Nevertheless, the selection and evaluative process that may lead to farmer evictions would work best when farmers hold individual rights to land. This is why it should be the norm for redistribution cases to adopt individual land leases or ownership, even when the land was originally acquired by a group. In cases where a community is purchasing the land, different types of incentives can be designed to promote performance and accountability. Nonperformance at a community or individual level should not be rewarded.

\section{Farmland subdivisions for productive activities}

The following discussion acknowledges that (1) although the Subdivision of Agricultural Land Act (1970) was repealed in 1998, it remains effective as instructed by the constitutional

\footnotetext{
8.Nevertheless, within a developmental state approach efforts to inspire and guide beneficiary communities to becoming productive and self-reliant should always be made through varied skills development programmes including through extension made through varied skills development programmes including through extension
services. A more self-reliant citizenry would also imply a decreasing burden on the fiscus.
}

court in 2008 until new guidelines are provided by the legislature, and (2) reviewed data indicate that there is a range somewhere between two and five hectares of acceptable farm sizes. On average, sizes below 1 hectare seem to be poverty traps (FAO 2015). Sizes of 2 hectares seem to be a global convergence for productive capacity. Five hectares seems like the ceiling and reasonable norm for efficient small farms especially in countries where farming is not technologically intensive. For different types of production systems, there would be different points where diseconomies (Appendix 1) start creeping in given factors including deteriorating quality of oversight and management of increasing input resources, including the management of increasing labour resource units. So, although there is theoretical and empirical support for smaller farms, this still does not mean however that any small size farm would be efficient, as illustrated for cases of farms smaller than a hectare and characterised by the high levels of poverty reported in some East African countries (FAO 2015). In those countries it is mainly the hunger for scarce land resources and big populations that determine farm sizes, not efficiency considerations. This discussion does not advocate the types of small farms that are not efficient and that are associated with poor living conditions. In any case a guideline for what farm size would make for the most efficient farm on average, cet. par., is important.

Historically, and from theory and empirical evidence, the ILO and other development agencies have promoted the idea that smaller farms outperform bigger ones (Harbeson 1971; Kanyinga 2016; Lowder et al. 2016; Rutten 1997). This thinking also informed Kenya's policy to promote smaller subdivisions of farmlands for more efficient household productivity. In the review of Zimbabwe and South Africa's land reform, arguments for smaller farms are also supported, for efficiency and the promotion of land markets (Lyne 2014). Lowder et al. (2016:16-29) present data of about 150 million farms globally showing that average farm sizes have converged towards just under two hectares in the last five decades. Their data set contains sub-Saharan African and high-income countries contributing $9 \%$ and $4 \%$, respectively, to total number of farms. There are indications that farm sizes in high-income countries have always been smaller than two hectares while in former colonies average farm sizes have declined dramatically since the 1960s, most probably with land reform projects ensuring more equitable land distributions. These trends are illustrated in Figure 1. Farm sizes are smaller in developed countries most likely because of they use more technology.

Of the high-income countries, Australia presents opposite trends where average farm sizes increased from less than 2000 to over 3000 hectares between 1960 and 2000 (Lowder et al. 2016:23). In South Africa farm sizes have also remained larger than the global average, with medium scale commercial farms between 55 and 216 hectares (Lyne 2014:5). With the Subdivision of Agricultural Land Act of 1970 still effective this is likely to remain the case for a while. In any case, $85 \%$ of farms globally are smaller than two hectares, 


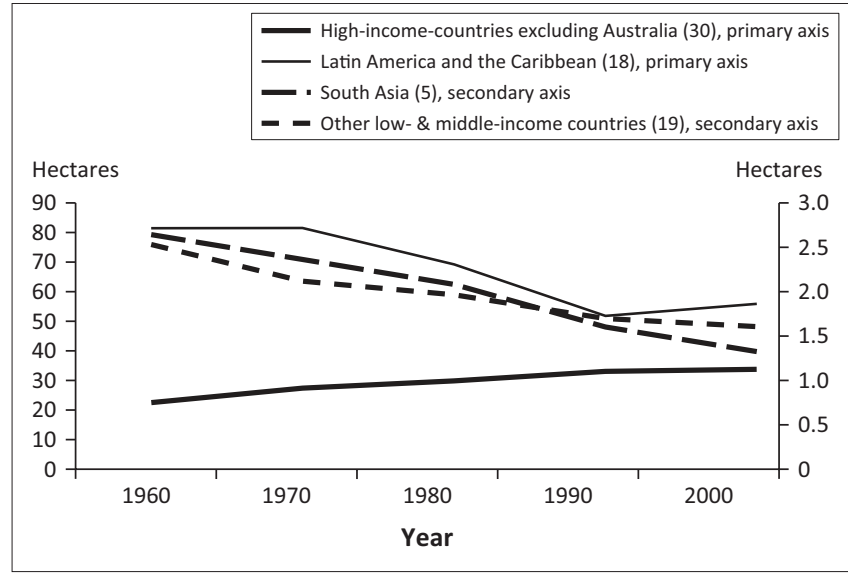

Source: Lowder, S.K., Skoet, J. \& Raney, T., 2016, 'The number, size, and distribution of farms, smallholder farms and family farms worldwide', World Development 87, 16-29. https://doi. org/10.1016/j.worlddev.2015.10.041

FIGURE 1: Average farm sizes, 1960-2000.

and only $6 \%$ are bigger than 5 hectares. Based on these trends it would be reasonable and risk adverse to advocate for the floor size of farms to be around 2 hectares and for five hectares to be the ceiling of small efficient cultivation farms. ${ }^{9}$ The decision on where in this range efficient farm size subdivisions could lie in South Africa would also depend on factors including, the type of crop cultivation considered, climate conditions, water availability, technology use, etc. These factors should guide broadly the subdivisions of land in redistribution projects or other projects where communities display aspirations to farm commercially. Given these broad guidelines, each business case would still require more indepth research for more accuracy in determining the most appropriate unit sizes.

What should be clear from evidence is that Australian and South African farm sizes are out of synch with global trends in both low- and high-income countries. They cannot be used as guides for how farms should be subdivided for black economic empowerment in agriculture. This is an important point to stress for South Africa given the country's history of adopting a number of natural resource management policy models from Australia in the last 20 years, for example the Integrated Water Resources Management framework (Madigele, Snowball \& Fraser 2015).

\section{Incentive schemes for promoting production by a monitoring and evaluation body}

The proposed typology, with the required human infrastructure, cannot design, establish and execute itself. Therefore an overarching and coordinating body would be required to implement and manage it. In this light, some of the principles from Ostrom $(1990,1992)$ that were outlined for managing common resources sustainably would be useful. The coordinating body should encourage the productive use of land by groups or individuals in redistribution cases through appropriate incentive schemes. This should include providing farmers with support in terms of skills, networks,

9. Most definitely farm sizes below 2 hectares, although prevalent may be too risky and not economically and politically sustainable given the farming conditions described in FAO (2015) for such farms in low-income countries including Ethiopia and Kenya. markets, etc. The body should ensure that agricultural extension services are the centre of skills development and provide not only practical farming skills to beneficiaries, but also skills to run successful businesses, networks, and skills for interpreting the land reform policy landscape. Through appropriate disincentives the body should prevent poor performances and take action against defaulters. The body should work at national and local levels with coordination, monitoring and evaluation functions performed by qualified experts. It is noted that some of these responsibilities are already stated as aspirations in the Land Reform Strategic Plan (LRSP) (2015-2020) of the Department of Rural Development. Some of the functions have been assigned to the Valuator General in the Property Valuation Act No.17 (2014). It would therefore make sense to locate the body in the office of the Valuator General.

\section{Summary and concluding remarks}

The framework proposed in this discussion is primarily an analytical and guiding tool for understanding and supporting various types of land reform projects. It is a tool potentially useful for policy formulation and implementation as well as for research. Its key elements are depicted in Figure 2, showing potential responses to questions that normally arise at different stages of implementing and evaluating land reform projects. For example, before an evaluation of whether or not a land resettlement project has been a failure one would need to first know whether or not the project in question was a land restitution or redistribution case. If it was a redistribution project, then a different set of expectations and guidelines would apply with respect to (1) what kind of ownership rights should be promoted by state agencies in that project, (2) and for what purpose the land resources in that project should be used, (3) how the land should be managed, (4) how it should be subdivided and demarcated, etc.

If the land project in question falls under the restitution programme, then how the land is used after resettlement would depend more on the wishes and aspirations of new owners. For such projects it must be remembered that many other sociological uses are possible beyond economic and agricultural ones. Figure 2 illustrates some examples of land for such projects. It is also possible that portions of land under restitution projects can later form part of empowerment programmes for economic benefits, whether those are agricultural or not. In those instances land portions for economic uses should be clearly demarcated and managed like a redistribution project between its owners and the state. The terms of how farming units are subdivided and envisaged businesses are managed, should be evaluated using criteria similar to those used for redistribution purposes. In this sense, the typology provides guidelines for responding to potential questions in the course of implementing land reform projects. It is a guide that should be used with careful consideration in different contexts. It should also evolve with more lessons over time. Given that many other competing and growing economic uses of land 


\section{Mapping out land reform projects - for practitioners \& researchers)}

Overarching coordinating, monitoring \& evaluation process (expert panel)

a. Applies relevant incentives (accept proposals / reward performance / reject non performance/ skills \& network support

b. Active links to broader economy

A. What type of resettlement in question?

A. Restitution cases:

a. Land claim/s by a collective or

an individual

a. Mostly collective rights to use or own land - legal entity (Ostrom's principles)

a. Traditional/Cultural system - with custodian Chief (Ostrom's principles on operations \& finances)

a. Possible individual ownership rights - full tradable rights

C. What type of land use? continuum

a. Sociological uses expected:

(burial, warship, community gatherings, resource preservation, etc.)

b. non-agric businesses (eg. enviro. Tourism)

c. agric activity - e.g. subsistence farming

d. Demarcated separate commercial agric business

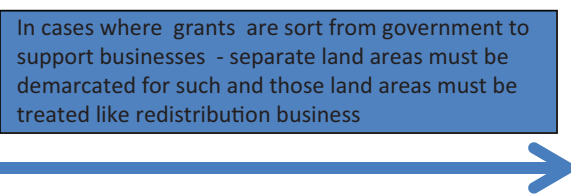

D. What type of business management? continuum

a. Mostly outsourced business managers (skills and networks)

b. Depending on skills availability - owners can be managers

of all or some business aspects

D. What are applicable subdivisions of land?

a. Encourage: separate smaller farms ( $>2$ to 5 ha)

for agric. business - where

E. What are applicable incentives schemes?

a. Active support/development on

stated business ventures

\section{A. Redistribution cases: \\ a. Request by a collective or an individual}

a. Mostly from individual lease to ownership rights

b.Allowable collective lease to ownership rights - legal entity (Ostrom principles applicable on operations \& finances)

c. Lease to tradable title deeds on performance incentive (reasonable review cycle period - eg. 3 to 5 years)

d. Lease can be revoked on performance (reasonable review cycle eg 3 to 5 years)

a. Demarcated primary commercial uses are a must,

b. Separate subsistence use cites permissible

c. Separate sociological use cites permissible

a. Owners are managers or strongly involved

b. Owners can have managers for aspects they don't have skills \& networks

a. Smaller farms more efficient where advanced Te. lacks

b. $>2$ ha to 5 ha -range: depending -climate; agric. Business, etc.

c. Past performance \& business proposal determines additional land unit increases ( each at $>2$ to 5 ha range)

a. Lease to tradable title deeds: performance

\& farmer contribution based

a. Revision of rights: performance based

b. Active farmer support \& development

FIGURE 2: Typology of guidelines for land reform projects.

resources are emerging; for example, environmental protection and tourism, it is important to note that for different uses different versions of this typology would have to be conceptualised to guide practitioners and researchers in implementation and evaluation.

\section{Acknowledgements \\ Competing interests}

The author declares that he has no financial or personal relationships that may have inappropriately influenced him in writing this article.

\section{References}

Ahmad, M. \& Quresh, S.K., 1999, 'Recent evidence on farm size and land productivity: Implications for public policy', The Pakistan Development Review 38(4) 1135-1153.

CDE, 2008, Land reform in South Africa, Centre for Development Enterprise, CDE Research No. 16, viewed 20 December 2008, from http://wwwcde.org.za/article. php?a_id $=284$

Cliffe, L., 2011, 'Land issues under power-sharing: Comparing Kenya and Zimbabwe', African Studies Bulletin 72, 91-116.

Conradie, B., 2007, 'What do we mean when we say casualisation of farm work is rising?: Evidence from fruit farms in the Western Cape', Agrekon 46(2), 173-197. https://doi.org/10.1080/03031853.2007.9523767

DLA, 1997, White paper on South African Land Policy, Department of Land Affairs (South Africa), Pretoria.
FAO, 2009, A review of experiences of establishing emerging farmers in South Africa: Case lessons and implications for farmer support within land reform programmes, Food and Agriculture Organization of the United Nations, Rome, Italy.

FAO, 2015, The economic lives of smallholder farmers: An analysis based on household data from nine countries, Food and Agriculture Organisation of the United Nations, Rome, Italy.

Frantz, G., 2010, 'Repealing the subdivision of agricultural land act: A constitutional analysis', Master of Laws degree thesis, University of Stellenbosch, Stellenbosch.

Harbeson, J.W., 1971, 'Land reform and politics in Kenya, 1954-70', The Journal of ModernAfrican Studies 9(2), 231-251. https://doi.org/10.1017/S0022278X00024915

Hall, R, 2009 'Land reform for what? Land use, production and livestock', in R. Hall (ed.), Another countryside? Policy options for land and agrarian reform in South Africa, pp. 23-62, Institute for Poverty, Land and Agrarian Studies, University of the Western Cape, Bellville.

Hardin, G., 1968, 'The tragedy of the commons', Science New Series 162(3859), $1243-1248$.

Lowder, S.K., Skoet, J. \& Raney, T., 2016, 'The number, size, and distribution of farms, smallholder farms and family farms worldwide', World Development 87, 16-29. https://doi.org/10.1016/j.worlddev.2015.10.041

LRC, 2017, Zuma's land claim remarks 'Misleading', Legal Resource Centre, viewed 15 May 2017, from http://Irc.org.za/Ircarchive/other-news/3208-zuma-s-land-claimremarks-misleading

LRSP, 2015-2020, Land reform strategic plan, Department of Rural Development and Land Reform, Republic of South Africa, Pretoria.

Lyne, M.C., 2014, 'The F.R. Tomlinson Memorial Lecture: Two decades of land reform in South Africa: Insights from an agricultural economics', Agrekon 53(4), 1-15. https://doi.org/10.1080/03031853.2014.975413

Lyne, M.C. \& Darroch, M.A.G., 2003, Land redistribution in South Africa: Past performance and future policy. Basics CRSP management entity, University of Natal, Pietermaritzburg.

Kanyinga, K., 2016, Kenya experience in land reform: The million-acre settlement scheme, Workshop discussion paper, viewed 22 May 2017 from http://siteresources. worldbank.org/RPDLPROGRAM/Resources/459596-1168010635604/WBIKenyaLandReform-WorkshopVersion.pdf 
Kinsey, B.H., 1999, 'Land reform, growth and equity: Emerging evidence from Zimbabwe's resettlement programme', Journal of Southern African Studies 25(2), Zimbabwe's resettlement programme', Journal of Southe

Madigele, P., Snowball, J. \& Fraser, G., 2015, 'Water, water everywhere: Is integrated water resource management the right institutional prescription for South Africa's wate management challenges?', paper presented at the Economic Association of South Africa (ESSA) viewed 14 August 2017 from https://w Africa (ESSA), vict $q=$.

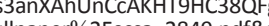
列

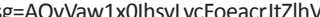

Mail and Guardian, 2015, Rushing land reform only slows it down, viewed 20 August 2015, from https://mg.co.za/article/2015-08-06-rushing-land-reform-only-slows-it-down

Mamdani, M., 1996, Citizen and subject: Contemporary Africa and the legacy of late colonialism, Princeton University Press, Princeton, NJ.

Mbatha, N.C. \& Antrobus, G.G., 2012, 'A cooperative benefits framework in South Africa's land redistribution process: The case of sugarcane farmland transfers', Agrekon 51(4), 81-104. https://doi.org/10.1080/03031853.2012.741207

Mbatha, N.C., Antrobus, G.G. \& van Rooyen, J., 2010, 'Land price premiums in South Africa's land redistribution process: A case study of Northern KwaZulu-Nata sugarcane farms', Agrekon 49(2), 235-254.

Mbatha, N.C. \& Muchara, B., 2015, 'Slow progress in South Africa's land reform process: Fear of property rights and free markets?', Journal of Green Economy and Development 1(2), 1-23, viewed n.d., from https://journalofgreeneconomy. wordpress.com/jged-volume-1-issue-2/

Moyo, S., 1986, 'The land question', in I. Mandaza (ed.), Zimbabwe: The political economy of transition 1980-1986, pp. 165-201, CODESRIA, Dakar.

Moyo, S., 2000, 'The political economy of land redistribution in the 1990s', in T.A.S Bowyer-Bower \& C. Stoneman (eds.), Land reform in Zimbabwe: Constraints and prospects, pp. 73-82, Ashgate, Aldershot.

NDP, 2011, National development plan vision 2013, Republic of South Africa, viewed 21 August 2017, from http://www.polity.org.za/article/national-developmentplan-vision-for-2030-november-2011-2011-11-14

Neves, D., 2006, 'The land question', in K. Ratele (ed.), Inter-group relations: South African perspectives, pp. 193-212, Juta \& Company, Cape Town.

Ostrom, M.E., 1990, Governing the commons: The evolution of institutions for collective action: Political economy of institutions and decisions, Cambridge University Press, New York.
Ostrom, M.E., 1992, Crafting institutions for self-governing irrigation systems, ICS Press, San Francisco, CA.

The South African Government, 1913, Native Land Act 27, Government Gazette 861, Pretoria.

The South African Government, 1970, Subdivision of Agricultural Land Act 70, 1970, Republic of South Africa, Government Gazette, Government Printers, Pretoria.

The South African Government, 1994, Restitution of Land Rights Act 22, Republic of South Africa, Government Gazette, Government Printer, Pretoria.

The South African Government, 1998, Subdivision of Agricultural Land Act Repeal Act 64, 1998, Republic of South Africa, Government Gazette, Government Printers, Pretoria.

The South African Government, 2014a, Property Valuation Act 17, Republic of South Africa, Government Gazette, Government Printers, Pretoria.

The South African Government, 2014b, Restitution of Land Rights Amendment Bill Act 15, 2014, Republic of South Africa, Government Gazette, Government Printer, Pretoria.

Rutten, M.M.E.M., 1997, 'Land reform in Africa: Lessons from Kenya', in A.L. Naerssen, M.M.E.M. Rutten \& A. Zoomers (eds.), The diversity of development, Van Gorcum, Assen, viewed 01 August 2017, from https://openaccess.leidenuniv.nl/bitstream/ handle/1887/9138/ASC_1268319_017.pdf?sequence=1

Scoones, I., Marongwe, N., Mavedzenge, B., Murimbarimba, F., Mahenene, J. \& Sukume, C., 2010, Zimbabwe's land reform: Myths and realities, Jacana Media, Johannesburg.

State President, 2013, Willing buyer, willing seller principle to go, viewed 01 May 2017, from http://www.fin24.com/Economy/Willing-buyer-seller-principle-to-go20130214

Terblanche, S.E., Stevens, J.B. \& Sekgota, M.G., 2014, 'A comparative analysis of two land reform models: The Mashishimale Farm management model and the Nkumbuleni strategic partnership model, South Africa', South African Journal of Agricultural Extension 42(2), 81-102.

The Conversation, 2016, 'South Africa's land reform efforts lack a focus on struggling farmers', viewed 20 April 2017, from https://theconversation.com/south-africasland-reform-efforts-lack-a-focus-on-struggling-farmers-69249

Thomas, N.H., 2010, 'Land reform in Zimbabwe', Third World Quarterly 24(4), 691-712. https://doi.org/10.1080/0143659032000105821 


\section{Appendix 1}

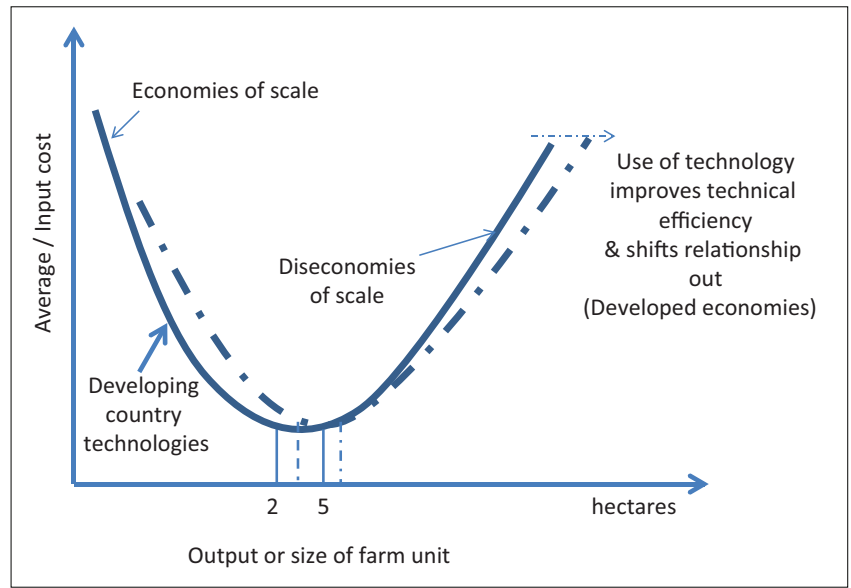

Note: Farms are producing most efficiently when production costs are lowest - somewher between 2 and 5 hectares. Farms that are smaller than 2 hectares are not efficiently productive and many of those are reported for developing countries such as Ethiopia (e.g. FAO, 2015). The conditions of farmers in those units are poor and should not be advocated through South African policy. The same applies to farms bigger than 5 hectares, where bis parts of farms lie idle. With the introduction of advanced technology it is also possible to shift the whole production schedule to the right in such a way that bigger farms in terms of size are more efficient.

FIGURE 1-A1: Economies and diseconomies of scale. 